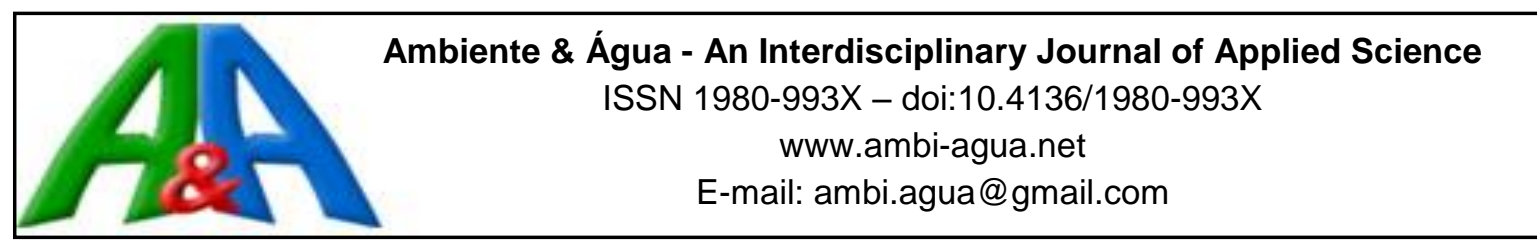

\title{
Selection of variables in the definition of a water quality index for the Brazilian Federal District
}

\author{
ARTICLES doi:10.4136/ambi-agua.2385
}

Received: 25 Feb. 2019; Accepted: 10 Jun. 2019

\author{
Ana Luiza Litz Passos ${ }^{1}$; ; Daphne Heloisa de Freitas Muniz ${ }^{\text {(D); }}$ \\ Leandro Pin Rangel ${ }^{3}$; ; Eduardo Cyrino Oliveira-Filho ${ }^{*}$ (D) \\ ${ }^{1}$ Universidade de Brasília (UnB), Brasília, DF, Brasil \\ Programa de Pós-graduação em Ciências Ambientais (UnB/FUP). E-mail: analuizalitz@ gmail.com \\ ${ }^{2}$ Embrapa Cerrados, Planaltina, DF, Brasil \\ Laboratório de Química Analítica de Água. E-mail: daphne.muniz@embrapa.br \\ ${ }^{3}$ Centro Universitário de Brasília (UniCEUB), Brasília, DF, Brasil \\ Faculdade de Ciências da Educação e Saúde (FACES). E-mail: leandro.rangel5@ gmail.com \\ ${ }^{4}$ Embrapa Cerrados, Planaltina, DF, Brasil \\ Centro de Pesquisa Agropecuária dos Cerrados. E-mail: eduardo.cyrino@embrapa.br \\ "Corresponding author
}

\begin{abstract}
Water Quality Indices (WQIs) are based on a small number of variables that establish categories for water quality. This method presents some problems with the evaluations, since WQIs do not consider the multiple uses of the water or differences in regional characteristics. The present study proposes a regional and more appropriate variable group for the definition of a Water Quality Index for the Brazilian Federal District, based on water quality monitoring of surface waters in the region. The monitoring was carried out monthly between August 2016 and July 2017, at three points on the Jardim River, Sobradinho Stream and Sarandi Stream, where 21 variables were evaluated. Among physical-chemical and microbiological analyses, the regional characteristics of these water bodies were noted, as well as their differences, and the main anthropogenic interferences that generate changes in water quality. In the urban area, the disposal of treated sewage from the wastewater treatment plant of Sobradinho was highlighted as the main anthropic interference, and agricultural activities stood out in the rural region of the study area. The impacts in the urbanized area were of greater weight. Thus, based on the results of the Principal Component Analysis (PCA), two groups of variables were selected, one representative of urban areas and the other of rural areas, to compose two probable water quality indices (WQIs) for the Federal District.
\end{abstract}

Keywords: Brazilian Federal District, regional variables, surface water, WQI.

\section{Seleção de variáveis na definição de um índice de qualidade de água para o Distrito Federal}

\section{RESUMO}

Os Índices de Qualidade da Água - IQAs, baseiam-se em um pequeno número de variáveis que estabelecem categorias para a qualidade da água. Esse método apresenta alguns problemas quanto às avaliações, pois os IQAs não consideram os usos múltiplos da água, bem como as diferenças nas características regionais. O presente estudo tem como objetivo propor um grupo

This is an Open Access article distributed under the terms of the Creative Commons
Attribution License, which permits unrestricted use, distribution, and reproduction in any
medium, provided the original work is properly cited.


de variáveis regional e mais apropriado para a definição de um Índice de Qualidade de Água para o Distrito Federal, baseado no monitoramento da qualidade de água de rios da região. Foi realizado monitoramento mensal entre agosto de 2016 a julho de 2017, em três pontos do Ribeirão Sobradinho, do Córrego Sarandi e do Rio Jardim, onde foram avaliadas 21 variáveis. Dentre análises físico-químicas e microbiológicas, foram observadas as características regionais desses corpos hídricos, bem como suas diferenças, e as principais interferências antrópicas que geram alteração na qualidade da água. Destacou-se na área urbana como principal interferência antrópica o descarte do esgoto tratado da estação de tratamento de esgoto de Sobradinho, e as atividades agropecuárias na região rural da área de estudo. Os impactos da área urbanizada foram de maior proporção. Dessa forma, baseado nos resultados da Análise de Componentes Principais - ACP, foram selecionados dois grupos de variáveis, sendo um representativo para a áreas urbanas e outro para áreas rurais, para compor dois prováveis índices de qualidade da água para o Distrito Federal.

Palavras-chave: água superficial, Distrito Federal Brasileiro, IQA, variáveis regionalizadas.

\section{INTRODUCTION}

Knowledge of the environmental characteristics of a given region is a basic tool for its sustainable development. In this context, studies on natural resources are included, and water appears to be one of the most important (Saad et al., 2007). In conflicts over water use, there is a pressing need for the establishment of tools capable of responding with agility and confidence to questions related to water use in Brazil. The monitoring and evaluation of surface water quality are key factors for the appropriate management of water resources (ANA, 2018). Monitoring water quality should be seen as a means of verifying its potability for human consumption. Several economic activities carried out in Brazil, such as agribusiness, can generate negative socio-environmental impacts for water resources (Medeiros et al., 2016).

Another important anthropic activity that generates environmental impact is the disposal of waste in water systems, as well as the use and occupation of the soil. These aspects have a direct relation with water quality, thus reaffirming the need to monitor water quality in a way that observes the characteristics of the water resource in the face of anthropic impacts (Costa and Ferreira, 2015).

The Brazilian Federal District (FD) is the Brazilian Federative Unit of the country with the third-lowest surface water availability per capita per year. In recent years, the Federal District has been experiencing strong population growth. In seven years (2010-2017), the total FD population grew $18.2 \%$, more than double the national average (8.1\%) (IBGE, 2017). Population growth in the FD does not only affect water consumption, but also leads to the inadequate use of natural resources, which implies environmental impacts. Thus, effective and rapid methods to monitor water quality are often necessary for the FD (Bilich and Lacerda, 2005).

In Brazil, the main tools related to the monitoring of water quality are the Water Quality Index (WQI) proposed by the São Paulo State Environmental Company (CETESB) (Zagatto et al., 1999; ANA, 2018), and the maximum values allowed by Resolution 357/05 of Brazilian Environment Council (CONAMA, 2005). Although these tools are important, they do not consider the multiple uses of water or regional characteristics, respectively (Passos et al., 2018). WQIs aim to give a unique value to the quality of the water body, so the formulation and use of indices have been strongly defended by agencies responsible for the supply and control of water pollution. Since data on water quality are collected through sampling and analysis, the need arises to translate the results in a way that is easily understood (Abbasi and Abbasi, 2012).

It is worth noting that Brazil, as a country with a continental dimension and different

Rev. Ambient. Água vol. 14 n. 4, e2385 - Taubaté 2019 
regional conditions, with wide climatic and geomorphological variation, possessing seven biomes, three ecotones and 79 ecoregions (Arruda et al., 2008), exemplifies how necessary it is to know the characteristics of water (Oliveira-Filho et al., 2014). This is because the impacts of any activity on water bodies can only be measured if there is prior knowledge of the natural conditions of the resource.

Variable selection is the first and most important step in the composition of any WQI. In an attempt to reduce subjectivity in the selection of variables, statistical analyses such as Principal Component Analysis (PCA) have been widely adopted (Abassi and Abassi, 2012). For Bollman and Marques (2000), the use of statistical calculations in the selection of variables aims to reduce uncertainties and increase the applicability of the indices. In this context, the present work aims to select more appropriate variables with the natural configuration of the Brazilian Federal District (FD), by means of PCA, to compose a water quality index for FD water bodies. According to Lemos (2011), water quality is determined by its physical, chemical and microbiological characteristics; however, quality is a very broad term and has as its basis the intended use. As in the present study there was no specific direction for the use of water, the water in its natural condition was understood as being of standard quality. Therefore, the interruption or modification of the natural conditions was considered to represent a change in the natural quality, making it possible to characterize variables of regional importance.

\section{MATERIALS AND METHODS}

\subsection{Study Areas and Sample Collection}

The Federal District is located in central Brazil, with an area of 5,789.16 km² (Barbosa, 2010), representing the soil diversity of the Cerrado (savanna) region. It is in the Central Plateau ecoregion, with a significant geoenvironmental variety (Arruda et al., 2008), reaching altitudes of up to 1,300 meters (Bilich and Lacerda, 2005). About $85 \%$ of FD soils are represented by the classes of Red Latosol, Yellow Red Latosol and Cambisol (Campos and Silva, 2000). The climate is characteristic of the Cerrado biome, with well-defined seasons: rainy summer and dry winter. In April, the dry season begins, ending around September; from October to March higher rainfall rates can be observed (Muniz et al., 2011).

In the Federal District, the São Bartolomeu Basin is the one with the largest extension, covering approximately $50 \%$ of the total area, representing $2,864.05 \mathrm{~km}^{2}$ (Barbosa, 2010). The sub-basins belonging to the São Bartolomeu River have significant importance in the activities of rural and urban areas. Its area consists of rural training and agricultural activities that correspond to approximately $70 \%$ of the area, and urbanization corresponds to approximately $4 \%$ of the area (Ferreira, 2006; Sena-Souza et al., 2013). Although urbanization is present in a smaller part of this river basin, it presents considerable impacts, since the disorderly urban expansion from the 90's generated environmental degradation in the area (Barbosa, 2010).

In order to identify the characteristics of the surface waters of the Federal District and to qualify the variables, one river and two streams were examined: Jardim River, from the Rio Preto Basin; and Sobradinho and Sarandi Streams, from the São Bartolomeu Basin (Figure 1). The fact that there was a natural area or an area under use, whether urban or agricultural, was considered for the selection. The fact that there was both natural or areas under human use, either under urban or agricultural, it was a factor taken under consideration for sample selection.

The water bodies selected in the São Bartolomeu River Basin were Sobradinho and Sarandi Streams, an urban and rural water body, respectively. Sobradinho Stream rises in the Canastra hill and is the main water body of the Hydrographic Unit of Ribeirão Sobradinho. It presents an altimetry amplitude of approximately $350 \mathrm{~m}$ and average annual temperature around $22^{\circ} \mathrm{C}$. In relation to land use and occupation, this region is marked by intense subdivision, which has increased significantly since the 1990s (Zoby and Duarte, 2001). Sarandi Stream is a tributary 
of the right bank of the Mestre d'Armas River, both belonging to the Hydrographic Unit of the Upper São Bartolomeu River, located in the north of the Federal District, with a drainage area of approximately $30 \mathrm{~km}^{2}$. The use and occupation of the soil of this area is characterized by agricultural activities and land allotments (Assis et al., 2013; Carvalho, 2005).

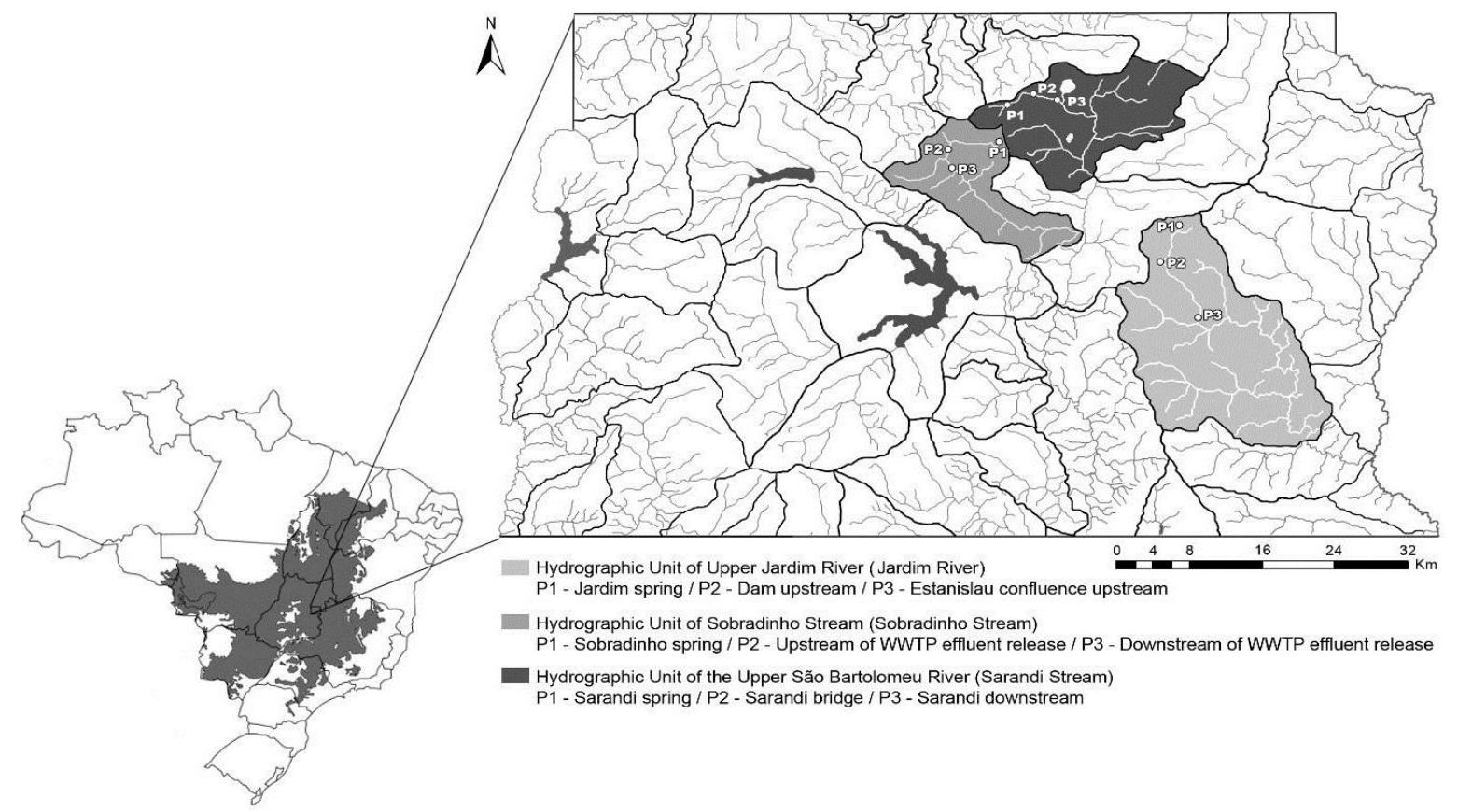

Figure 1. Location of the study area.

The Rio Preto Basin includes, besides the Federal District (12.94\%), the states of Goiás (22.01\%) and Minas Gerais (65.05\%), so it is defined as a federal river. In the Federal District, this hydrographic basin corresponds to approximately $23 \%$ of the total area, with drainage of $1,343.75 \mathrm{Km}^{2}$ (Barbosa, 2010). Its use is mainly for agriculture, and it is responsible for about $80 \%$ of the agricultural production of the Federal District. The Rio Preto Basin is a major contributor to the São Francisco River, which is an important source of energy generation, irrigation and supply of human needs (Oliveira-Filho and Parron, 2007).

The Jardim River comprises a total drainage area of $141.8 \mathrm{~km}^{2}$. It is located in the Hydrographic Unit of the Upper Jardim River, east of the Federal District, framed in the Rio Preto Basin, which is an affluent of the Paracatu River, a considerable tributary of the São Francisco River (Castro et al., 2016). It is a predominantly rural area with intense agricultural activity (Vieira et al., 2018), used for the cultivation of several crops, leaving few areas of its natural vegetation bordering the river (Lima, 2010).

The collection points were defined based on the representativeness of the point in the river and the safety of sampling. Previous studies in the basins also helped to define the sampling sites (Muniz et al., 2011; Pires et al., 2015), and the surveys carried out at the sites contributed information about the characteristics of the areas and the main polluting activities of the region (ANA, 2012). The springs were selected to observe the natural characteristics of the rivers, without direct anthropogenic interference. The other two points were aimed at assessing the impact of different human activities on the river. Samplings occurred monthly between August 2016 and July 2017, with 12 samplings from each point in each water body, totaling 108 samples, 36 from each river.

In the Sobradinho Stream, the collection points were denominated: P1, Sobradinho Spring (15 37'59' S and 47 46'21' W); P2, upstream of WWTP (wastewater treatment plant) effluent

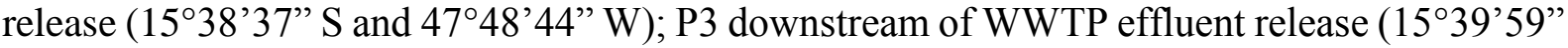


S and $\left.47^{\circ} 48^{\prime} 32^{\prime \prime} \mathrm{W}\right)$. In the Sarandi Stream, collection points were described as: P1, Sarandi

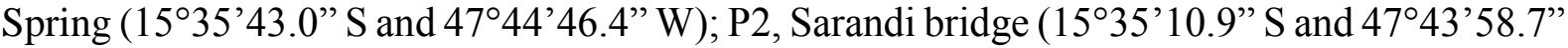

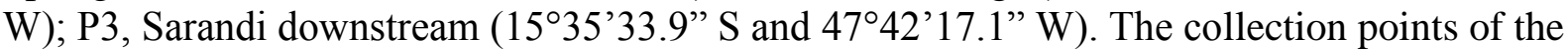

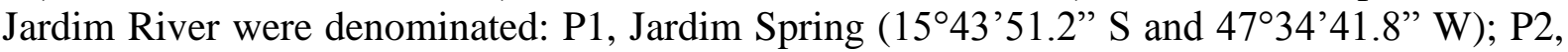
dam upstream $\left(15^{\circ} 45^{\prime} 54.9^{\prime \prime} \mathrm{S}\right.$ and $\left.47^{\circ} 35^{\prime} 34.80^{\prime \prime} \mathrm{W}\right)$; P3, Estanislau confluence upstream $\left(15^{\circ} 49^{\prime} 44.3 " \mathrm{~S}\right.$ and $\left.47^{\circ} 33^{\prime} 28.9^{\prime \prime} \mathrm{W}\right)$.

In the water body, about $40 \mathrm{~cm}$ from the river bank, the properly prepared $300 \mathrm{ml}$ polyethylene bottles were dipped into the water to a depth of approximately $30 \mathrm{~cm}$. After collection, the vial was stored in a cool box under refrigeration and protected from light until it reached the laboratory for analysis. For determination of total coliforms and Escherichia coli, samples were collected in appropriate sterile containers containing sodium thiosulfate, 0.1 $\mathrm{mg} / 100 \mathrm{~mL}$ sample. All samples were subjected to physical, chemical and microbiological analysis. Samples destined for ionic analysis by chromatography were filtered through a hydrophilic membrane, consisting of mixtures of cellulose esters with $0.45 \mu \mathrm{m}$ porosity and frozen until the moment of analysis.

\subsection{Laboratory and Statistical Analysis}

For each sample, 21 variables were analyzed: 19 physicochemical and 2 microbiological variables: temperature (TEMP), dissolved oxygen (DO), $\mathrm{pH}$, electrical conductivity (EC), total dissolved solids (TDS), turbidity (TURB), total hardness (TH), total dissolved phosphorus (TDP), sodium $\left(\mathrm{Na}^{+}\right)$, potassium $\left(\mathrm{K}^{+}\right)$, ammonium $\left(\mathrm{NH}_{4}{ }^{+}\right)$, calcium $\left(\mathrm{Ca}^{2+}\right)$, magnesium $\left(\mathrm{Mg}^{2+}\right)$, fluoride $\left(\mathrm{F}^{-}\right)$, chloride $\left(\mathrm{Cl}^{-}\right)$, nitrite $\left(\mathrm{NO}_{2}{ }^{-}\right)$, nitrate $\left(\mathrm{NO}_{3}{ }^{-}\right)$, phosphate $\left(\mathrm{PO}_{4}{ }^{3^{-}}\right)$, sulfate $\left(\mathrm{SO}_{4}{ }^{2-}\right)$, total coliforms and Escherichia coli (E. coli).

The variables temperature and dissolved oxygen were obtained in the field with the use of a portable multiparameter meter HQ40d Hach, and the other analyses were carried out in the Embrapa Cerrados Water Chemistry Laboratory in compliance with the Brazilian Association of Technical Standardization (ABNT, 1992) and the 22nd edition of Standard Methods for the Examination of Water and Wastewater - SMEWW (APHA, 2012).

In the statistical analyses, the data matrix of Sobradinho Stream, Sarandi Stream and Jardim River were submitted to descriptive statistics (mean and standard deviation), in order to synthesize the data to have an overview of the results.

Principal Component Analysis (PCA) was used to rewrite multivariate data (Lattin et al., 2011). With this analysis, it was possible to observe similar variables that can have the same meaning in terms of water quality. PCA provides a smaller view of the data that are in high dimensions, and explains as much of the data variance as possible in its first components (axes). The results of the PCAs of this study helped to select variables that contributed to the greater variability in water quality for the proposal of a water quality index for the DF. The statistical treatment of the data was carried out using software R version 3.4.2 (R Core Team, 2017). In the PCA analysis, the 'vegan' packages were used (Oksanen et al., 2017) and 'FactoMineR' (Le et al., 2008).

\section{RESULTS AND DISCUSSION}

\subsection{Physical and Chemical Analyses}

The data of the 19 physical-chemical variables obtained in this study show a significant difference between the water quality of Sobradinho Stream and Sarandi Stream and Jardim River (Table 1). The change in the values of P1 (spring) to P3 (downstream of the WWTP) of Sobradinho Stream occurred in more variables and in a greater proportion than in the other two rivers. Observing the averages of each physicochemical parameter of Sobradinho Stream (Table 1), it is possible to verify that the TDS increased about 90 times from P1 to P3, the hardness increased by about 70 times, ammonium showed an increase of about 50 times from the source 
to the P3, the conductivity increased approximately 40-fold, the chloride had a magnification of about 25 times, total dissolved phosphorus and nitrate increased approximately 20-fold and potassium and turbidity also increased by about 15 and 10 times, respectively from P1 to P3.

The TDS is the junction of dissolved chemical compounds in water; its main sources are agricultural activities, point sources such as WWTP and industrial outflow (Parron et al., 2011), and this would explain its considerable increase in P3, due to the WWTP point of Sobradinho. The same applies to the increase in hardness, which indicates contamination in the water, since it is a natural characteristic of it to present extremely low values in environments without direct anthropogenic interference (Aquino et al., 2009). The main ions that provide hardness in water are calcium and magnesium, which are often interconnected with sulfate ions (Di Bernardo and Dantas, 2005).

The variables total dissolved phosphorus (TDP), potassium $\left(\mathrm{K}^{+}\right)$and ammonium $\left(\mathrm{NH}_{4}{ }^{+}\right)$ follow the same pattern, with the highest values found in P3 and the lowest values in P1. These variables extrapolated the values allowed in P3 in several months (CONAMA, 2005). According to Parron et al. (2011), high values of these variables may indicate contamination of raw sewage, transport of fertilizers and industrial effluents.

Chloride $\left(\mathrm{Cl}^{-}\right)$is strongly related to the discharge of sanitary sewage, since human excreta contain a high amount of this element (WHO, 2017), which explains its increase in P3. However, even though P3 shows the highest value for this parameter, it is still lower than the maximum values allowed by CONAMA, which is $250 \mathrm{mg}$. $\mathrm{L}^{-1}$. In some months, $\mathrm{P} 3 \mathrm{Nitrate} \mathrm{NO}_{3}{ }^{-}$ exceeded the values stipulated by CONAMA Resolution 357/2005, with the majority of these months in the dry period. It is believed that the reduction in water volume increased $\mathrm{NO}_{3}{ }^{-}$. The $\mathrm{NO}_{3}{ }^{-}$and $\mathrm{Cl}^{-}$are considered relevant ions in the indication of contamination by urban effluents (Muniz et al., 2011).

The study by Muniz et al. (2011) in Sobradinho Stream also showed considerable changes in the water quality as it approached the urban area. Urbanization is strongly connected with the decrease in water quality (Silva et al., 2009), with P3 being within an urban environment. As in this study, Muniz et al. (2011) found the highest DO values at the spring and their lowest values at P3. CONAMA Resolution $\mathrm{N}^{\circ} 357 / 2005$ states that Class I fresh water must not have DO of less than $6 \mathrm{mg} . \mathrm{L}^{-1}$, Class II must not be less than $5 \mathrm{mg} . \mathrm{L}^{-1}$ and Class III not less than 4 mg. $\mathrm{L}^{-1}$; that is, the minimum found in the creek is below the value determined for Class IV of the CONAMA resolution framework, in which it indicates that the DO should not be less than $2 \mathrm{mg} . \mathrm{L}^{-1}$. This is probably due to the location of P3, which is downstream of Sobradinho's WWTP outflow, at a distance of approximately 600 meters (INPE, 2018). The bacteria that are present in large amounts in the WWTP effluent use oxygen in their respiratory processes during the stabilization of organic matter, which may contribute to the reduction of DO levels in water (Alves et al., 2008). The electrical conductivity (EC) showed a considerable increase downstream of the WWTP. Because this parameter is related to the presence of ions in the water body, the more inorganic compounds are present in the solution, the greater its conductivity (APHA, 2012).

Slightly acidic values and low $\mathrm{pH}$ variation were also observed. The slightly acidic $\mathrm{pH}$ is a characteristic of Cerrado waters, which reproduce the acidity of the soils of this biome (Pires et al., 2015). Sarandi Stream and Jardim River presented fewer variables with large changes between P1 and P3 (Table 1). In Sarandi, only nitrate, turbidity and TDS increased considerably, even though in much lower proportions than in Sobradinho. The nitrate increased about 6 times and the turbidity about 4 times, and the TDS almost doubled. In the Jardim River, in addition to the TDS, which also almost doubled from P1 to P3, nitrate increased by approximately 23 times, regarding the mean of P1 to the mean of P3, while fluoride increased about 5 times, and the potassium, calcium, magnesium and conductivity almost doubled. 
Table 1. Descriptive statistics of the physical and chemical variables analyzed at the collection points of Sobradinho Stream, Sarandi stream and Jardim river.

\begin{tabular}{|c|c|c|c|c|c|c|c|c|c|c|c|c|c|c|c|c|c|c|}
\hline \multirow{3}{*}{ Variables } & \multicolumn{6}{|c|}{ Sobradinho Stream } & \multicolumn{6}{|c|}{ Sarandi Stream } & \multicolumn{6}{|c|}{ Jardim river } \\
\hline & \multicolumn{3}{|c|}{$\mathbf{M}$} & \multicolumn{3}{|c|}{ SD } & \multicolumn{3}{|c|}{$\mathbf{M}$} & \multicolumn{3}{|c|}{ SD } & \multicolumn{3}{|c|}{$\mathbf{M}$} & \multicolumn{3}{|c|}{ SD } \\
\hline & P1 & $\mathbf{P 2}$ & P3 & P1 & $\mathbf{P 2}$ & P3 & P1 & $\mathbf{P 2}$ & P3 & $\mathbf{P 1}$ & $\mathbf{P 2}$ & P3 & $\mathbf{P 1}$ & $\mathbf{P 2}$ & P3 & P1 & $\mathbf{P 2}$ & P3 \\
\hline $\mathrm{TEMP}^{\circ} \mathrm{C}$ & 22.75 & 21.36 & 21.40 & 1.26 & 1.24 & 0.93 & 21.48 & 23.78 & 22.64 & 1.46 & 1.29 & 1.41 & 21.65 & 21.86 & 22.18 & 1.20 & 1.39 & 1.16 \\
\hline $\mathrm{DO}\left(\mathrm{mg} \mathrm{L}^{-1}\right)$ & 5.56 & 5.65 & 3.04 & 1.07 & 0.77 & 1.89 & 7.65 & 7.15 & 6.86 & 0.54 & 0.23 & 0.39 & 7.17 & 7.35 & 7.25 & 0.66 & 0.35 & 0.37 \\
\hline $\mathrm{pH}$ & 5.23 & 6.45 & 6.80 & 0.54 & 0.25 & 0.48 & 6.15 & 5.96 & 5.56 & 0.45 & 0.59 & 0.47 & 5.94 & 5.95 & 5.98 & 0.49 & 0.49 & 0.50 \\
\hline $\mathrm{EC}(\mu \mathrm{S} / \mathrm{cm})$ & 4.57 & 62.80 & 170.4 & 1.61 & 22.47 & 77.96 & 3.88 & 5.02 & 5.88 & 0.81 & 0.71 & 1.21 & 3.98 & 7.57 & 7.85 & 1.03 & 1.64 & 4.10 \\
\hline TDS $\left(\mathrm{mg} \mathrm{L}^{-1}\right)$ & 1.81 & 33.26 & 90.01 & 0.73 & 6.48 & 36.70 & 1.37 & 1.89 & 2.38 & 0.44 & 0.36 & 0.60 & 1.89 & 3.14 & 3.29 & 1.74 & 0.76 & 1.93 \\
\hline $\mathrm{TH}\left(\mathrm{mg} \mathrm{L}^{-1}\right)$ & 0.40 & 16.25 & 70.08 & 0.76 & 10.28 & 88.52 & 2.83 & 2.50 & 3.21 & 1.70 & 1.31 & 1.50 & 3.83 & 4.83 & 4.33 & 2.08 & 3.33 & 2.71 \\
\hline TURB (UNT) & 3.80 & 13.44 & 35.59 & 5.57 & 13.74 & 33.70 & 2.63 & 3.63 & 10.11 & 1.94 & 2.29 & 15.53 & 6.12 & 12.55 & 9.67 & 4.68 & 13.26 & 6.42 \\
\hline $\mathrm{TDP}\left(\mathrm{mg} \mathrm{L}^{-1}\right)$ & 0.024 & 0.023 & 0.396 & 0.02 & 0.04 & 0.27 & 0.002 & 0.002 & 0.001 & 0.001 & 0.001 & 0.001 & 0.007 & 0.002 & 0.018 & 0.001 & 0.001 & 0.05 \\
\hline $\mathrm{Na}^{+}\left(\mathrm{mg} \mathrm{L}^{-1}\right)$ & 0.29 & 0.43 & 0.74 & 0.12 & 0.64 & 0.98 & 0.15 & 0.19 & 0.15 & 0.15 & 0.20 & 0.14 & 0.50 & 0.44 & 0.55 & 0.30 & 0.17 & 0.19 \\
\hline $\mathrm{K}^{+}\left(\mathrm{mg} \mathrm{L}^{-1}\right)$ & 0.17 & 3.44 & 15.92 & 0.26 & 2.90 & 11.53 & 0.17 & 0.33 & 0.22 & 0.09 & 0.23 & 0.20 & 0.32 & 0.26 & 0.58 & 0.32 & 0.17 & 0.82 \\
\hline $\mathrm{NH}_{4}{ }^{+}\left(\mathrm{mg} \mathrm{L}^{-1}\right)$ & 0.71 & 16.06 & 32.20 & 0.47 & 8.42 & 19.72 & 0.81 & 1.40 & 1.03 & 0.23 & 0.72 & 0.74 & 1.28 & 1.71 & 3.09 & 1.24 & 3.30 & 6.86 \\
\hline $\mathrm{Ca}^{2+}\left(\mathrm{mg} \mathrm{L}^{-1}\right)$ & 3.12 & 9.55 & 12.74 & 2.15 & 4.47 & 1.95 & 1.46 & 1.56 & 1.78 & 0.23 & 0.21 & 0.39 & 1.67 & 2.40 & 3.00 & 1.46 & 2.08 & 4.21 \\
\hline $\mathrm{Mg}^{2+}\left(\mathrm{mg} \mathrm{L}^{-1}\right)$ & 0.23 & 0.94 & 1.74 & 0.16 & 0.37 & 0.43 & 0.30 & 0.29 & 0.26 & 0.06 & 0.07 & 0.10 & 0.30 & 0.49 & 0.57 & 0.21 & 0.21 & 0.49 \\
\hline $\mathrm{Fl}^{-}\left(\mathrm{mg} \mathrm{L}^{-1}\right)$ & 0.02 & 0.05 & 0.18 & 0.03 & 0.09 & 0.10 & 0.03 & 0.02 & 0.01 & 0.05 & 0.04 & 0.02 & 0.01 & 0.03 & 0.05 & 0.02 & 0.03 & 0.05 \\
\hline $\mathrm{Cl}^{-}\left(\mathrm{mg} \mathrm{L}^{-1}\right)$ & 0.96 & 6.78 & 22.76 & 2.07 & 3.22 & 13.72 & 0.47 & 0.69 & 0.64 & 0.19 & 0.31 & 0.38 & 0.57 & 1.15 & 1.79 & 0.31 & 2.05 & 4.26 \\
\hline $\mathrm{NO}_{2}^{-}\left(\mathrm{mg} \mathrm{L}^{-1}\right)$ & n.d & n.d & 12.81 & 0.01 & n.d & 29.68 & 0.03 & n.d & n.d & 0.09 & n.d & n.d & n.d & n.d & n.d & n.d & n.d & n.d \\
\hline $\mathrm{NO}_{3}^{-}\left(\mathrm{mg} \mathrm{L}^{-1}\right)$ & 0.79 & 6.02 & 14.99 & 1.70 & 3.56 & 24.89 & 0.06 & 0.08 & 0.37 & 0.09 & 0.14 & 0.33 & 0.08 & 0.49 & 1.83 & 0.08 & 1.10 & 5.52 \\
\hline $\mathrm{PO}_{4}{ }^{3-}\left(\mathrm{mg} \mathrm{L}^{-1}\right)$ & n.d & n.d & 2.25 & n.d & n.d & 2.43 & n.d & n.d & n.d & n.d & n.d & n.d & n.d & n.d & 0.09 & n.d & n.d & 0.30 \\
\hline $\mathrm{SO}_{4}{ }^{2-}\left(\mathrm{mg} \mathrm{L}^{-1}\right)$ & n.d & 0.15 & 0.20 & n.d & 0.36 & 0.49 & n.d & n.d & n.d & n.d & n.d & n.d & n.d & 0.01 & 0.01 & n.d & 0.02 & 0.02 \\
\hline
\end{tabular}

$\mathrm{M}=$ Mean $/ \mathrm{DP}=$ Standard Deviation $/ \mathrm{P} 1=$ Point $1 / \mathrm{P} 2=$ Point $2 / \mathrm{P} 3=$ Point 3/ TEMP $=$ Temperature $/ \mathrm{DO}=$ Dissolved oxygen $/ \mathrm{EC}=$ Electrical conductivity $/ \mathrm{TDS}=$ Total dissolved solids $/ \mathrm{TH}=$ Total hardness $/ \mathrm{TURB}=$ Turbidity $/ \mathrm{TDP}=$ Total Dissolved Phosphorus $/$ n.d $=$ non detected . 
In the rivers of the rural area the parameter with the greatest variation was nitrate. This increase can be explained by the agricultural activity of the region (Aquino et al., 2009). Both rivers presented values lower than those found in Sobradinho Stream, and the anthropogenic interference is different. This was because in Sobradinho Stream, the wastewater treatment plant (WWTP) was observed as clearly being the main source of water quality changes, whereas in Sarandi Stream and Jardim River, which are located in rural environments, the main interference is agriculture and livestock. The widespread agricultural activity in the Jardim River region, which leads to intense use of agrochemicals, can cause water contamination (Muniz et al., 2011), which is the possible explanation for the increase of nitrate at P3 of this river.

A common feature observed in the three monitored water bodies is the low values detected in their springs for the hardness, and it is natural for these waters to always have low hardness (Aquino et al., 2009; Muniz et al., 2011; Oliveira-Filho et al., 2014); thus, it is believed that when this parameter changes, resulting in higher values, it signals the point at which anthropic interference occurs.

\subsection{Total Coliforms and $E$. coli}

In the results of the microbiological analyses of Sobradinho Stream, high values were observed for Total Coliforms (TC) at P2 and P3 for all samples taken. With the exception of P2 in June, all samples were detected with values > 2,419.6 MPN (Most Probable Number) / 100 mL. According to CONAMA Resolution No. 357/2005, total coliforms are acceptable up to the value of 5,000 MPN / $100 \mathrm{~mL}$. Also according to this standard, Class III waters used in recreation of secondary contact should not exceed the limit of 2,500 MPN / $100 \mathrm{~mL}$ in $80 \%$ or more of at least 6 samples, and for the watering of animals raised in confinement the limit is $1,000 \mathrm{NMP} / 100 \mathrm{~mL}$ in $80 \%$ or more of at least 6 samples. E. coli showed the lowest values at P1 and the highest values at P3, as well as TC. P1 and P2 presented acceptable values for the use of secondary-contact recreation, as well as for watering animals in confinement. In contrast, P3 exceeded all limits determined by CONAMA throughout the E. coli sampling for the use of the stipulated activities. The main explanation for the high values of TC and mainly of $E$. coli at P3 of Sobradinho is the release of WWTP effluents. The presence of E. coli in the water bodies means there is fecal contamination through these microorganisms (Silva and Bringuel, 2007).

At P1 of Sarandi Stream the TC value was the highest among the three rivers. In some months, the P2 of both Sarandi and Jardim presented values > 2,419.6 MPN / $100 \mathrm{~mL}$, and in Jardim this value was found more frequently at P2 and Sarandi at P3. The values found in these two water bodies are within the allowed limits (CONAMA, 2005).

The $E$. coli amounts found in these water bodies are probably associated with animal feces (cattle ranching) and a small amount of untreated sewage (Aquino et al., 2009; Muniz et al., 2011).

CONAMA Resolution No. 357/2005 (CONAMA, 2005) was used throughout the research, with the minimum and maximum values stipulated as the basis for qualifying each parameter.

\subsection{Principal Component Analysis}

Before the principal component analyses (PCA) took place, Kaiser-Meyer-Olkin index (KMO) and Bartlet Sphericity Test (BST) measurements were carried out. For Hair et al. (2009), KMO values greater than 0.5 to 1.0 are considered acceptable for PCA application. The result of the KMO index obtained in the first study matrix was 0.79 and the BST was considered significant $(<0.000, \mathrm{p}<0.05)$.

Principal component analysis (PCA) was performed on the total set of normalized data (21 variables) for the 9 sampling points in order to observe the dispersion diagram of the three water bodies (Figure 2). 


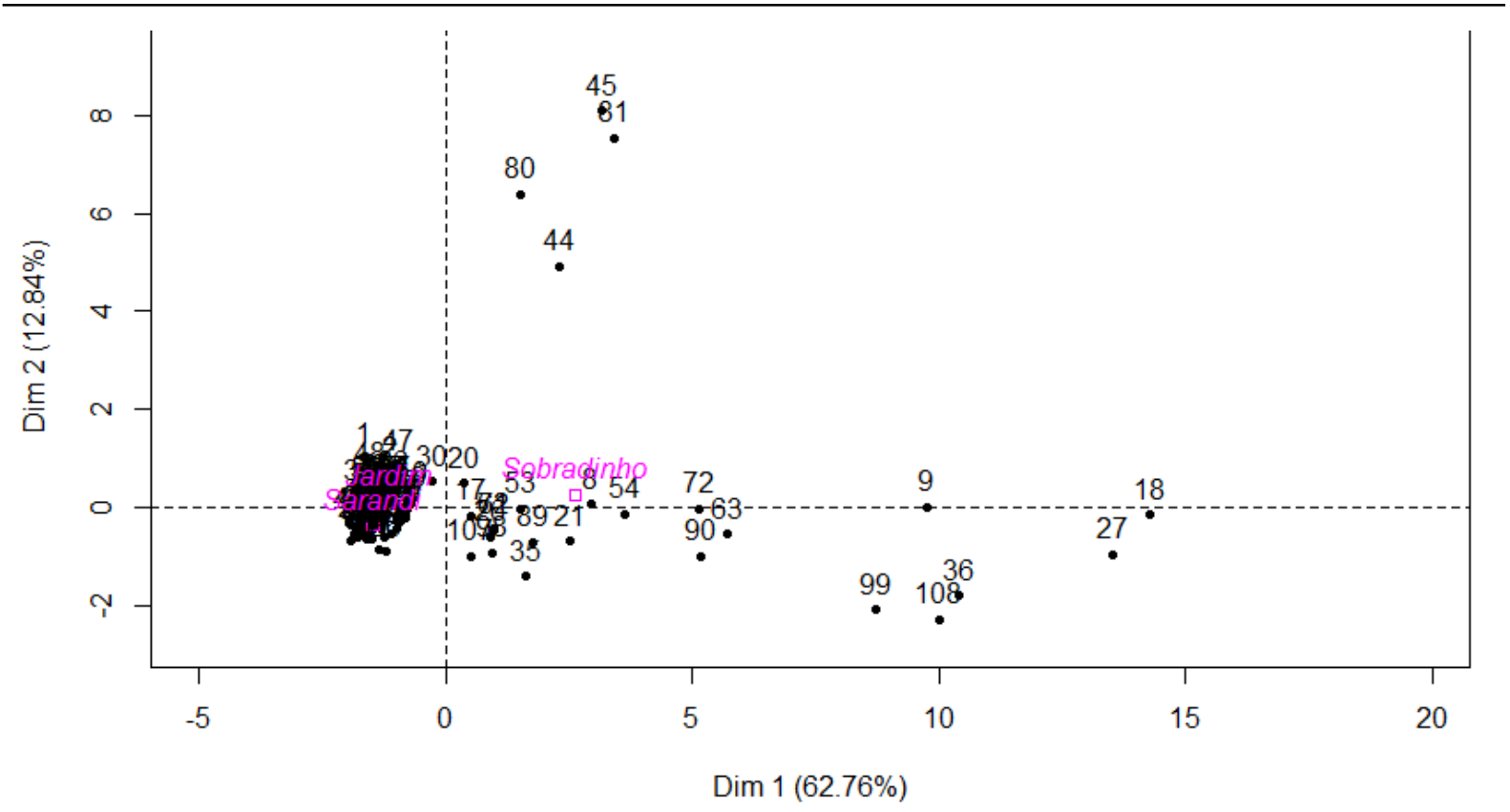

Figure 2. Dispersion diagram of water bodies sampled in main components 1 and 2.

It is possible to observe how the general characteristics of Sobradinho differ from Sarandi and Jardim, and how the latter two are similar. The probable explanation for this is that Sobradinho Stream is an urban water body, with a specific source of pollution provided by Sobradinho's WWTP, while the similarity between Sarandi and Jardim is possibly due to the fact that both are in rural areas, with agriculture and livestock as a source of anthropogenic contamination.

After the result of the dispersion diagram (Figure 2), showing the difference between Sobradinho and the other two rivers, a PCA was generated from Sobradinho Stream and a PCA with Sarandi Stream and Jardim River together (Table 2), in order to observe the ordered variables.

For the Sobradinho Stream data set $(\mathrm{KMO}=0.82$ and BST $=\mathrm{p}<0.000)$ and the Sarandi Stream and Jardim River $(\mathrm{KMO}=0.77$ and $\mathrm{BST}=\mathrm{p}<0.000)$ the first two components $(\mathrm{PC} 1$ and PC2) were selected, because they presented eigenvalues $>1$, based on the Kaiser criterion, and the total percentage explained between 70 and $90 \%$ according to the criterion adopted by Jolliffe (Kaiser, 1958; Jolliffe, 2002). In studies that use PCA in water quality assessment, the first two or three major components generated account for much of the variation in the original data. In most cases these components are sufficient to describe the entire data matrices without significant loss of information (Simeonov et al., 2003). A Varimax normalization was applied as a rotation method in the analysis of the main components for better interpretation of the results. For Sobradinho Stream, the two components explained $75.06 \%$ of the original data variation, while in Sarandi Stream and Jardim River the total variation explained by the three components was $80.77 \%$ (Table 2).

Loads greater than 0.75 were established to consider the variable with an important load in the main component. Liu et al. (2003) classified values of absolute load>0.75, 0.75-0.5 and 0.5-0.3 as strong, moderate and weak, respectively. For the Sobradinho Stream data set, the variables DO, EC, TDS, potassium, ammonium, magnesium, fluoride, chloride, phosphate and E. coli presented loads above 0.75 for PC1 and the sodium and sulfate variables likewise in PC2. In the data set of Sarandi Stream and Jardim River, TDP, potassium, ammonium, calcium, magnesium, chloride, nitrate and phosphate presented strong loads in PC1, while EC, TDS and sulfate had loads $>0.75$ in PC2 (Table 2). 
Table 2. Loadings of the main components, eigenvalues, percentage of variation and total percentage explained by the monitoring of the sampled water bodies.

\begin{tabular}{lcccc}
\hline \multirow{2}{*}{ Variables } & \multicolumn{2}{c}{ Sobradinho Stream } & Sarandi Stream and Jardim River \\
\cline { 2 - 5 } & $\mathbf{P C 1}$ & $\mathbf{P C 2}$ & $\mathbf{P C 1}$ & PC2 \\
\hline Temperature (TEMP) & -0.397 & -0.391 & -0.008 & -0.000 \\
Dissolved Oxygen (DO) & $\mathbf{- 0 . 8 3 2}$ & 0.021 & -0.126 & -0.116 \\
pH & 0.743 & 0.118 & -0.014 & 0.316 \\
Electrical Conductivity (EC) & $\mathbf{0 . 9 1 8}$ & 0.047 & 0.248 & $\mathbf{0 . 8 7 3}$ \\
Total Dissolved Solids (TDS) & $\mathbf{0 . 9 6 5}$ & -0.013 & 0.232 & $\mathbf{0 . 8 3 1}$ \\
Total Hardness (TH) & $\mathbf{0 . 7 5 6}$ & 0.069 & 0.228 & 0.528 \\
Turbidity $(\mathrm{TURB})$ & 0.636 & 0.347 & 0.006 & 0.065 \\
Total Dissolved Phosphorus (TDP) & 0.321 & 0.337 & $\mathbf{0 . 9 3 4}$ & -0.170 \\
Sodium $\left(\mathrm{Na}^{+}\right)$ & 0.093 & $\mathbf{0 . 8 6 9}$ & 0.042 & 0.165 \\
Potassium $\left(\mathrm{K}^{+}\right)$ & $\mathbf{0 . 8 8 1}$ & -0.218 & $\mathbf{0 . 8 7 6}$ & -0.096 \\
Ammonium $\left(\mathrm{NH}_{4}{ }^{+}\right)$ & $\mathbf{0 . 8 5 2}$ & -0.342 & $\mathbf{0 . 9 5 8}$ & -0.120 \\
Calcium $\left(\mathrm{Ca}^{2+}\right)$ & 0.721 & 0.253 & $\mathbf{0 . 9 4 8}$ & -0.034 \\
Magnesium $\left(\mathrm{Mg}^{2+}\right)$ & $\mathbf{0 . 9 0 4}$ & 0.114 & $\mathbf{0 . 8 9 1}$ & -0.001 \\
Fluoride $\left(\mathrm{F}^{-}\right)$ & $\mathbf{0 . 8 1 3}$ & -0.261 & 0.392 & 0.104 \\
Chloride $\left(\mathrm{Cl}^{-}\right)$ & $\mathbf{0 . 9 2 8}$ & -0.245 & $\mathbf{0 . 9 6 1}$ & -0.074 \\
Nitrite $\left(\mathrm{NO}_{2}^{-}\right)$ & 0.448 & -0.248 & -0.038 & -0.050 \\
Nitrate $\left(\mathrm{NO}_{3}{ }^{-}\right)$ & 0.456 & -0.294 & $\mathbf{0 . 9 7 3}$ & -0.103 \\
Phosphate $\left(\mathrm{PO}_{4}{ }^{3-}\right)$ & $\mathbf{0 . 7 9 8}$ & -0.168 & $\mathbf{0 . 9 3 9}$ & -0.160 \\
Sulfate $\left(\mathrm{SO}_{4}{ }^{-}\right)$ & -0.019 & $\mathbf{0 . 9 4 6}$ & 0.007 & $\mathbf{0 . 7 8 0}$ \\
Total Coliforms $(\mathrm{TC})$ & 0.599 & 0.359 & 0.093 & 0.132 \\
Escherichia coli $($ E. coli) & $\mathbf{0 . 8 0 1}$ & 0.404 & 0.152 & 0.471 \\
Eigenvalue & 9.610 & 2.400 & 7.199 & 2.494 \\
\% of Variation & 60.06 & 15.00 & 59.99 & 20.78 \\
\% Explained total & 75.06 & & 80.77 & \\
& & & &
\end{tabular}

\subsection{Proposal of variables for a regional WQI}

The differences observed in all the analyses of this work demonstrate the necessity of two separate groups of variables to constitute the FD Water Quality Index, one being an index for rivers in the urban environment and the other for rivers in the rural environment. For the proposal of these two groups of variables in the formation of WQIs for FD, the results of the PCA of Sobradinho Stream (Table 2) and PCA of Sarandi Stream and Jardim River together (Table 2) were considered, and the data of the physical and microbiological analyses (Table 1).

Electrical conductivity is a very significant variable in the analysis of water quality, since it can warn about high levels of many inorganic variables in the rivers. Besides the inorganic ions, it also shows good correlation with other variables. The conductivity showed a correlation with several inorganic ions in Sobradinho Stream, which can be interpreted as a warning for river pollution. This parameter was incorporated in the quality index of the urban and rural rivers, since its high values can signal the presence of possible contaminations and impacts undergone by rivers (Wanick et al., 2011) and mainly modifications in their mineral concentration (CETESB, 2009).

The TDS were also ordered in all PCAs, but the correlation between TDS and conductivity is high, so that only the conductivity will be proposed for the WQI of FD. Chloride was also selected in all PCAs, and is part of the proposal in the group of variables for urban and rural 
WQIs. Calcium was selected in the rural area, since this variable presented high loading and being very sensitive to changes in the rural environments studied.

Potassium, ammonium and magnesium variables were also ordered in the PCA of Sobradinho Stream, and of Sarandi Stream and Jardim River. These variables presented changes from P1 to P3 in the analyzed water bodies, and they were therefore suggested for the urban and rural WQIs of the FD.

Phosphate and sulfate appeared in low amounts in all water bodies in this study. The selection of them by PCA must have occurred because they presented a variation. Indeed, at many points their presence was not detected, and at some points in a few months, they were found. However, because they were detected in a few months and in low amounts throughout the monitoring, phosphate and sulfate are not proposed in the urban and rural WQIs of FD. Nitrate and total dissolved phosphorus were selected only in the PCA of the rural water bodies, and both variables are thus suggested in the rural WQI.

The variables that were selected only in the PCA of Sobradinho Stream were DO, total hardness, sodium, fluoride and E. coli. DO presented a negative correlation with several variables, but it was important in the evaluation of the urban water quality of FD.

The total hardness had an increase of about 70 times from P1 to P3 in this river. The water hardness, according to the results of the monitoring of this study, is low in natural waters, such as at a spring, but with the increase of anthropic intervention the values tend to get higher, making this parameter a sign of contamination in the water body. Sodium and fluoride are significant variables, since they may present increased values in water due to effluents from wastewater treatment plants (CETESB, 2009; Parron et al., 2011).

E. coli is the main indicator of fecal contamination and the possible presence of pathogenic organisms (Brasil, 2017); the presence of this bacterium in high concentrations leaves water unfit for various activities (Silva and Bringuel, 2007). Although E. coli was not ordered in the PCA of the rural rivers, but it is an important microbiological parameter, as mentioned above, which meant that it was also incorporated in the rural WQI, mainly due to the potential presence of livestock in those areas.

Thus, among the 21 initial variables analyzed, it was proposed to select 10 variables for the definition of a WQI for urban areas, and 9 variables for a WQI for rural areas of the Brazilian FD. The variables selected for the urbanized regions and the rural regions in the FD are shown in Table 3, in comparison with the original variables from CETESB-WQI (Zagatto et al., 1999).

Table 3. Comparison among variables from original WQI CETESB and proposed by the present study for urban WQI and rural WQI to be defined for FD.

\begin{tabular}{lcc}
\hline WQI CETESB & Urban WQI & Rural WQI \\
\hline Dissolved Oxygen & Dissolved Oxygen & Electrical Conductivity \\
$\mathrm{pH}$ & Electrical Conductivity & Total Dissolved \\
Turbidity & Total Hardness & Phosphorus \\
Biological Oxygen Demand & Sodium & Potassium \\
Total Nitrogen & Potassium & Ammonium \\
Total Phosphorus & Ammonium & Calcium \\
Total Residues & Magnesium & Magnesium \\
Temperature & Fluoride & Chloride \\
Escherichia coli & Chloride & Nitrate \\
& Escherichia coli & Escherichia coli \\
\hline
\end{tabular}




\section{CONCLUSIONS}

The data obtained in this study from the monitoring of the rivers and the characterization of the water quality variables evidenced the differences between the water bodies.

Sobradinho Stream is a water body that is considered urban, because it crosses the town of Sobradinho and receives effluent from the wastewater treatment plant of this town, which considerably changes the quality variables. Sarandi Stream and Jardim River are considered rural water bodies, since both run mainly through an agricultural area. The main non-point source of changes in the water quality of these surface waters is the agricultural activities present near the watercourses.

Thus, based on the regional characteristics of the FD and on quality as meaning the maintenance of the natural condition, the present study evidenced the urgent need to establish two different WQIs for FD water quality. One can be exclusively for the definition of an urban WQI, composed of: DO, electrical conductivity, total hardness, sodium, potassium, ammonium, magnesium, fluoride, chloride and E. coli; and the other for the construction of an eminently rural WQI, consisting of electrical conductivity, total dissolved phosphorus, potassium, ammonium, calcium, magnesium, chloride, nitrate and E. coli. The definition of the weights for each parameter may be objects of other studies, when there is a need to define the respective use of waters.

The use of these variables divided into two groups could minimize water quality conflicts and help with planning and framing issues aiming at better management of water resources in the Brazilian Federal District.

\section{ACKNOWLEDGMENTS}

We thank the Fundação de Amparo à Pesquisa do Distrito Federal (FAP-DF) (process $n^{\circ}$ 193.001.354/2016) for financial support. Leandro Pin Rangel received grants from PIC/UniCEUB and PIBIC/Embrapa in subsequent years.

\section{REFERENCES}

ABBASI, T.; ABBASI, S. A. Water quality indices. [S.l.]: Elsevier, 2012. 362 p.

ABNT. Nbr 12621: Água - Determinação da dureza total - Método titulométrico do EDTA-Na Método de ensaio. Rio de Janeiro, 1992.

ALVES, E. C.; SILVA, C. F.; COSSICH, E. S.; TAVARES, C. R. G.; SOUZA FILHO, E. E.; CARNIEL A. Avaliação da qualidade da água da bacia do rio Pirapó - Maringá, Estado do Paraná, por meio de parâmetros físicos, químicos e microbiológicos. Acta Scientiarum Technology, v. 30, n. 1, p. 39-48, 2008.

ANA (Brasil). Portal da Qualidade das Águas. Available at: http://portalpnqa.ana.gov.br/default.aspx. Access: 20 Dec. 2018.

ANA (Brasil). Panorama da qualidade das águas superficiais do Brasil 2012. Brasília, 2012. 264p.

APHA. Standard methods for the examination of water and wastewater. 22. ed. Washington DC., 2012.

AQUINO, F. G.; VILELA, M. F.; CAMARGO, W. R. F.; CAMARGO, A. J. A.; OLIVEIRAFILHO, E. C.; PASSOS, F. B.; SOUSA, S. R. Uso e cobertura do solo, caracterização biótica e de qualidade da água como subsidio para a elaboração do plano de manejo da área da Embrapa. Planaltina, DF: Embrapa Cerrados, 2009. 50p. 
ARRUDA, M. B.; PROENÇA, C. E. B.; RODRIGUES, S.; MARTINS, E. S.; MARTINS, R. C.; CAMPOS, R. N. Ecorregiões, Unidades de Conservação e Representatividade Ecológica do Bioma Cerrado. In: SANO, S.; ALMEIDA, S.P.; RIBEIRO, J. F. Cerrado: ecologia e flora. Brasília: Embrapa, 2008. v. 1, p. 229-272.

ASSIS, T.; COUTO-JUNIOR, A. F.; NEVES, G.; REATTO, A.; MARTINS, E.S.; GOMES, M. P.; SENA-SOUZA, J. P.; REIS, A. M.; RAMALHO, L. S.; CLAUDINO, V. C. M. Evolução temporal da cobertura da terra de uma bacia experimental do Cerrado utilizando sensoriamento remoto multi sensor e multitemporal. In: SIMPÓSIO BRASILEIRO DE SENSORIAMENTO REMOTO - SBSR, 16., 2013, Foz do Iguaçu, PR. Anais[...] São José dos Campos: INPE, 2013. p. 7739-7745.

BARBOSA, R. P. Avaliação de riscos ambientais na região de Sobradinho, Distrito Federal. Dissertação. 2010. (Mestrado em Planejamento e Gestão Ambiental) Universidade Católica de Brasília, Brasília, 2010.

BILICH, M. R.; LACERDA, M. P. C. Avaliação da qualidade da água do Distrito Federal (DF), por meio de geoprocessamento. SIMPÓSIO BRASILEIRO DE SENSORIAMENTO REMOTO, 12., 2005, Goiânia. Anais[...]São José dos Campos: INPE, 2005. p. 20592065.

BOLLMAN, H. A.; MARQUES, D. M. Bases para Estruturação de Indicadores de Qualidade de Águas. Revista Brasileira de Recursos Hídricos, v. 5, p. 37-60, 2000.

BRASIL. Ministério da Saúde. Gabinete do Ministro. PCR n ${ }^{\circ}$ 5, de 28 de setembro de 2017. Anexo XX. Diário Oficial [da] União, Seção 1, n. 190, Brasília, DF, 03 out. 2017.

CAMPOS, J. E. G.; SILVA, F. H. F. Solos. In: FONSECA, F. O. Olhares sobre o Lago Paranoá. Brasília: Secretaria de Meio Ambiente e Recursos hídricos, 2000.

CARVALHO, P. R. S. A expansão urbana na bacia do Ribeirão Mestre d'Armas (DF) e a qualidade da água. Estudos Geográficos, n. 3, p. 71-91, 2005.

CASTRO, K. B.; ROIG, H. L.; LIMA J. E. F. W.; FERRIGO S. Aplicação de série temporal mínima para simulação de vazões em bacia experimental do Cerrado. Revista Brasileira de Cartografia, n 68/8, p. 1497-1513, 2016.

CETESB. Significado ambiental e sanitário das variáveis de qualidade da água e dos sedimentos e metodologias analíticas e de amostragem. São Paulo: Secretaria do Meio Ambiente, 2009.

CONSELHO NACIONAL DO MEIO AMBIENTE (Brasil). Resolução n ${ }^{\circ}$ 357, de 17 de março de 2005. Diário Oficial [da] União, Seção 1, p. 58-63, Brasília, DF, 18 Mar. 2005.

COSTA, F. B.; FERREIRA, V. O. Análise de Parâmetros que Compõem o Índice de Qualidade das Águas (IQA) na Porção Mineira da Bacia do Rio Paranaíba. Revista Eletrônica de Geografia, v. 7, n. 18, p. 22-47, 2015.

DI BERNARDO, L.; DANTAS, A. D. B. Métodos e técnicas de tratamento de água. São Carlos: RiMa, 2005. v. 2, 1565 p.

FERREIRA, C. S. Avaliação temporal do uso e ocupação das terras na bacia do Rio São Bartolomeu, DF. 2006. 115p. Dissertação (Mestrado) - Faculdade de Agronomia e Medicina Veterinária, Universidade de Brasília, Brasília, 2006. 
HAIR, J. J. F.; ANDERSON, R. E.; TATHAM, R. L.; BLACK, W. C. Análise multivariada de dados. 6. ed. Porto Alegre: Bookman, 2009. 593p.

IBGE. Diretoria de Pesquisas, Coordenação de População e Indicadores Sociais. Estimativas da população residente com data de referência 1 de julho de 2017. Available at: https://cidades.ibge.gov.br/brasil/df/panorama. Access: 2017.

INPE. Divisão de processamento de imagens - DPI. Available at: http://www.dpi.inpe.br/ Aceess: 2018.

JOLLIFFE, L.T. Principal component analysis. 2. ed. New York: Springer, 2002. 487p.

KAISER, H. F. The varimax criteria for analitical rotation in factor analysis. Psychometrica, v. 23, p. 187-200, 1958.

LATTIN, J.; CARROL, J. D.; GREEN, P. E. Análise de dados multivariados. 1. ed. [S.l.]: Cengage Learning, 2011.

LE, S.; JOSSE, J.; HUSSON, F. FactoMineR: An R Package for Multivariate Analysis. Journal of Statistical Software, v. 25, n. 1, p. 1-18, 2008.

LEMOS, W. E. D. Monitoramento e gestão da qualidade da água em reservatórios incorporando processos hidrodinâmicos e climáticos de regiões tropicais semiáridas. 2011. 164 f. Dissertação (Mestrado) - Universidade Federal do Ceará, Fortaleza, 2011.

LIMA, J. E. F. W. Modelagem numérica do fluxo da água no solo e do escoamento de base em uma bacia experimental em área agrícola no Cerrado. 2010. 312p. Tese (Doutorado em Tecnologia Ambiental e Recursos Hídricos) - Universidade de Brasília, Brasília, 2010.

LIU, C. W.; LIM, K. H.; KUO, Y. M. Application of factor analysis in the assessment of groundwater quality in a Blackfoot disease area in Taiwan. Science of the Total Environment, v. 313, p. 77-89, 2003. https://doi.org/10.1016/S0048-9697(02)00683-6

MEDEIROS, A. C.; LIMA, M. O.; GIMARÃES, R. M. Avaliação da qualidade da água de consumo por comunidades ribeirinhas em áreas de exposição a poluentes urbanos e industriais nos municípios de Abaetetuba e Barcarena no estado do Pará, Brasil. Ciência e saúde coletiva, v. 21, p. 695-705, 2016. https://doi.org/10.1590/141381232015213.26572015

MUNIZ, D. H. F.; MORAES, A. S.; FREIRE, I. S.; CRUZ, C. J. D.; LIMA, J. E. F. W.; OLIVEIRA-FILHO, E. C. Evaluation of water quality parameters for monitoring natural, urban, and agricultural areas in the Brazilian Cerrado. Acta Limnologica Brasiliensia, v. 23, p. 307-317. 2011. http://dx.doi.org/10.1590/S2179-975X2012005000009

OKSANEN, J.; BLANCHET, F. G.; FRIENDLY, M.; KINDT, R.; LEGENDRE, P.; MCGLINN, D.; MINCHIN, P. R.; O'HARA, R. B.; SIMPSON, G. L.; SOLYMOS, P.; STEVENS, M. H. H.; SZOECS, E.; WAGNER, H. Vegan: Community Ecology Package. $\mathrm{R}$ package version 2.4-5. Available at: https://CRAN.Rproject.org/package=vegan. Access: 2017.

OLIVEIRA-FILHO, E. C.; CAIXETA, N. R.; SIMPLICIO, N. C. S.; SOUSA, S. R.; ARAGÃO, T. P.; MUNIZ, D. H. F. Implications of water hardness in ecotoxicological assessments for water quality regulatory purposes: a case study with the aquatic snail Biomphalaria glabrata (Say, 1818). Brazilian Journal of Biology, v. 74, p. 175-180. 2014. http://dx.doi.org/10.1590/1519-6984.24212 
OLIVEIRA-FILHO, E. C.; PARRON, L. M. Avaliação de qualidade das águas no Brasil: O Rio Preto examinado. Espaço \& Geografia, v. 8, p. 71-86, 2007.

PARRON, L. M.; MUNIZ, D. H. F.; PEREIRA, C. M. Manual de amostragem e análise físico-química de água. Colombo: Embrapa Florestas, 2011.

PASSOS, A. L. L; MUNIZ, D. H. F.; OLIVEIRA-FILHO, E. C. Critérios para Avaliação da Qualidade de Água no Brasil: Um Questionamento sobre os Parâmetros Utilizados. Fronteiras: Journal of Social, Technological and Environmental Science, v. 7, n. 2, p. 290-303, 2018.

PIRES, N. L.; MUNIZ, D. H. F.; KISAKA, K.; SIMPLICIO, N. C. S.; BORTOLUZZI, L.; LIMA, J. E. F. W.; OLIVEIRA-FILHO, E. C. Impacts of the urbanization process on water quality of Brazilian savanna rivers: the case of Preto River in Formosa, Goiás State, Brazil. International Journal of Environmental Research and Public Health, v. 12, p. 10671-10686, 2015. https://doi.org/10.3390/ijerph120910671

R CORE TEAM. R: A language and environment for statistical computing. Vienna: $R$ Foundation for Statistical Computing, 2017. Available at: https://www.R-project.org/. Access: 2017.

SAAD, A. R.; SEMENSATTO JR., D. L.; AYRES, F. M.; OLIVEIRA, P. E. Índice de qualidade da água - IQA do reservatório do tanque grande, município de Guarulhos, estado de São Paulo, Brasil: 1990-2006. Revista UnG - Geociências, v. 6, n. 1, p. 118133, 2007.

SENA-SOUZA, J. P.; MARTINS, E. S.; COUTO JUNIOR, A. F.; REATTO, A.; VASCONCELOS, V.; GOMES, M. P.; CARVALHO JUNIOR, O. A.; REIS, A. M. Mapeamento Geomorfológico da Bacia Hidrográfica do Rio São Bartolomeu, escala 1:100,000. Boletim de Pesquisa e Desenvolvimento, v. 314, 39p, 2013.

SIMEONOV, V.; STRATIS, J. A.; SAMARA, C.; ZACHARIADIS, G.; VOUTSA, D.; ANTHEMIDIS, A.; SOFONIOU, M.; KOUIMTZIS, T. Assessment of the surface water quality in Northern Greece. Water Research, v. 37, p. 4119-4124, 2003.

SILVA, A. M.; ROSA, A. H.; ANTUNES, F. M.; NOGUEIRA, D. P; LESSA, S. S. Relationship between water quality and land use along a stretch of the Sorocaba river (SP). Journal of the Brazilian Society of Ecotoxicology, v. 4, p. 65-71. 2009.

SILVA, G. C; BRINGEL, J. M. M. Incidência de coliformes totais e Escherichia coli nas águas utilizadas para irrigação pela comunidade do município de paço do lumiar- MA. Revista Brasileira de Agroecologia, v. 2, p. 599-603, 2007.

VIEIRA, C. H. N.; MATTOS, L. M.; MALAQUIAS, J. V.; AQUINO, F. G.; MARTINS, P. T. A. Spatial and temporal land use and land cover of the Upper Jardim River Basin, Distrito Federal, Brazil. Revista Brasileira de Geografia Física, v. 11, n. 1, p. 085-098, 2018.

WANICK, R. C; MACEDO-SOARES, P. H. M; MACHADO, A. C; BRITTO, F. G. A; MURTA, A. L. S; FREITAS, M. A. V. Avaliação do IQA como ferramenta de avaliação da qualidade de água nos corpos hídricos interceptados pela rodovia BR-163 (Guaratã do Norte - MT). In: SIMPÓSIO BRASILEIRO DE RECURSOS HÍDRICOS, 19., 2011, Maceió. Anais[...] São Paulo: ABAS, 2011.

WHO. Chemical hazards in drinking-water. 2017. Available at: http://www.who.int/water_sanitation_health/dwq/chemicals/en/. Access: 2017. 
ZAGATTO, P.A., LORENZETTI, M.L., LAMPARELLI, M.C., SALVADOR, M.E.P., MENEGON JR, N., BERTOLETTI, E. Aperfeiçoamento de um índice de qualidade de águas. Acta Limnologica Brasiliensia, Rio Claro, v. 11, p. 111-126, 1999.

ZOBY, J. L. G.; DUARTE, U. Caracterização Hidrogeológica da Bacia do Ribeirão Sobradinho - Brasília (DF). Geologia USP Série Científica, v. 1, p. 79-99, 2001. 